\title{
Optimization of Extraction Condition and Characterization of Malva Verticillata Root Bark Mucilage
}

\author{
P. C. Korir ${ }^{1}$, A. M. Salim ${ }^{2}$, J. O. Odalo ${ }^{1}$, W. Waudo ${ }^{2}$, L. M. Gitu ${ }^{2}$, Amir O Yusuf $^{3}$ \\ ${ }^{1}$ Department of Pure and Applied Sciences, Technical University of Mombasa, Mombasa, Kenya \\ ${ }^{2}$ Department of Chemistry, Jomo Kenyatta University of Agriculture and Technology, Nairobi, Kenya \\ ${ }^{3}$ Department of Chemistry, University of Nairobi, Kenya \\ Correspondence: P. C. Korir, Department of Pure and Applied Sciences, Technical University of Mombasa, P.O. Box \\ 90420-80100, Mombasa, Kenya. E-mail: korircheruiyotpatrick@tum.ac.ke
}

Received: January 9, 2018 Accepted: February 8, 2018 Online Published: March 10, 2018

doi:10.5539/ijc.v10n2p1

URL: https://doi.org/10.5539/ijc.v10n2p1

\begin{abstract}
The study aimed at optimizing the extraction conditions and establishing the physicochemical properties of the mucilage obtained from root bark of Malva verticillata. Effects of temperature, time, particle size and amount of water as a solvent on the yield and composition of mucilage were established. Micrometric, physical, chemical and structural properties were used to characterise the extracted mucilage. Result showed significant correlation between extraction conditions and mucilage yield. Low temperature and short extraction time results into pharmaceutically valuable mucilage with low protein content, high viscosity and good dispersion in aqueous solvent. Large and small size particles of the plant material results into low mucilage yield without significant difference $(\mathrm{p}=0.054)$. The mucilage shows mixed cohesiveness with less tendencies to flow. It exhibits vibration bands in FTIR that are associated with the presence of polysaccharides and proteins. The mucilage contains $2.65 \%$ protein, $13.83 \%$ inorganics, $1.85 \%$ fats, and the rest carbohydrates. High extractive value $>80 \%$ and moisture content $>12 \%$ implies that mucilage has high tendency to microbial attack. Optimized extraction conditions results into high yield of the mucilage with the same physicochemical properties and mineral composition regardless of the plant material sampling sites.
\end{abstract}

Keywords: malva verticillata, mucilage, pharmaceutics, extraction condition

\section{Introduction}

Application of plant mucilages as pharmaceutical adjuvant requires characterization and optimization of extraction conditions as the physico-chemical properties vary with the type of plant, method of extraction and purification. There is need to optimize mucilage extraction conditions in order to enhance yield and achieve desired physical and chemical properties for pharmaceutical applications. Mucilage's are widely applied in the manufacture of drugs as tablet binders and both gelling and suspending agent. Plants have been established to be viable source of mucilage that can be exploited for pharmaceutical applications with a number of plant species being targeted for the coveted pharmaceutical adjuvant (Senthil, Gopalkrishnan, Ramajayam, \& Rahul, 2010; Alalor, Avbunudiogba, \& Augustine, 2014; Chaudhary, Kulkarni, Rajendra, \& Kumar, 2016).

Yield and physicochemical properties of mucilage obtained from different plant species varies with extraction conditions (Amin, Shamsuddin, Yinyin, Yahya, \& Ibrahim 2007). Mucilage yield increases with temperature and time of extraction. Thanatcha and Pranee, (2011) reported the significant effect of solvent on yield of mucilage. No thermal method of hydrating and agitation results in high yield than non-agitation method (Monrroy, García, Ríos, \& Renán, 2017). Mucilage precipitated by acetone is more soluble and swell totally in water than using ethanol (Patel, Shah, Mahajan, \& Dushyant, 2011). High temperatures and extended time of extraction yield mucilage with high viscosity and proteins content (Singthong, Ningsanond, \& Cui, 2009). Other researchers have reported the negative effect of high extraction temperature on proteins and viscosity of mucilage.

Mucilage's are high-molecular-weight, sticky and gummy substances which form dispersions in water. The Mucilage dispersion can be precipitated as amorphous or granular mass by organic solvents (Chaudhary et al., 2016). According to Goycoolea and Cardenas, (2003), mucilage consists of arabinose, galactose, mannose, xylose, uronic acids and acid resistant nucleus that can be hydrolysed enzymatically. Bruneton, (1999) classified mucilage as heterogeneous 
polysaccharide consisting of protein, starch and sugar. Alalor et al., (2014) reported mucilage as an ester of sulphuric acid with glycoside linkages with high-molecular-weight, sticky and gummy substances.

Malva verticillata $\mathrm{L}$. (Cluster mallow, Malvaceae) is often used as a vegetable as well as an herb in traditional medicine. Its leaves are alternate with five to seven lobes (Laurence, 2007). The roots of M. verticilata when peeled or soaked in water releases a sticky slippery fluid which can be precipitated by organic solvent as amorphous mass. The objective of this study was to optimise extraction condition and to determine composition of mucilage obtain from M. verticilata roots bark.

\section{Methods}

\subsection{Materials}

All reagents used were of analytical grade. Malva verticillata roots was collected from Nairobi Eastland (Sample A), Nairobi county and Kericho (Sample B), Kericho county, Kenya, after authentication by the Taxonomist. Sample specimen were preserved at Nairobi University Herbarium, Voucher number, PCK2015/01.

\subsection{Optimization of Extraction Method}

\subsubsection{Extraction of Mucilage}

Air dried root bark of M. verticilata were grounded into 149-250, 250-500 and 750-1000 $\mu \mathrm{m}$ fractions to open up mucilage cells. Each fraction was pre- treated with 95\% ethanol in a boiling-water bath for $1 \mathrm{hr}$ to leach out organic compounds as slurry. Distilled water containing $1 \%$ sodium metasulphite was added to the pre-treated mass at specified extraction conditions as shown in Table 1 below to extract the mucilage. The whole mass was strained through a fourfold muslin cloth to separate filtrate from the marc. Filtrate was then centrifuge at $3000 \mathrm{rpm}$ for $10 \mathrm{mins}$ to precipitate out insoluble fibre. $95 \%$ ethanol at equal volume was added to the supernatant to separate out mucilage as crude solid mass. The crude mucilage was washed with acetone and dried in an oven. Crude mucilage was then purified by back extracting with water and deproteinating with chloroform $/ \mathrm{n}$-butanol $(\mathrm{v} / \mathrm{v}=4: 1)$ in boiling water bath for 10 mins. Mucilage was then precipitated out by adding 95\% ethanol before drying in an oven at $45{ }^{\circ} \mathrm{C}$ for 2 hrs. Dry Malva verticillata mucilage (MVM) was passed through BSS no. $60(250 \mu \mathrm{m})$ before storing in air tight bags at room temperature.

Table 1. Mucilage extraction conditions

\begin{tabular}{cccccc}
\hline & & \multicolumn{2}{c}{ Independent Variables } & \multicolumn{2}{c}{$\begin{array}{c}\text { Dependent } \\
\text { Variable }\end{array}$} \\
\hline Coded level & $\begin{array}{c}\text { Amount of solvent per g of MV Powder } \\
\mathrm{mL} / \mathrm{g}\end{array}$ & $\begin{array}{c}\text { Time in } \\
\text { hours }\end{array}$ & $\begin{array}{c}\text { Temperature in } \\
{ }^{\circ} \mathrm{C}\end{array}$ & $\begin{array}{c}\text { Particle size in } \\
\mu \mathrm{m}\end{array}$ & $\begin{array}{c}\text { Yield of Mucilage } \\
\mathrm{g} / \mathrm{g}\end{array}$ \\
\hline $\mathbf{- 1}$ & 10 & 1 & 25 & $149-250$ \\
\hline $\mathbf{0}$ & 15 & 3 & 50 & $250-500$ \\
\hline $\mathbf{+ 1}$ & 20 & 6 & 75 & $500-750$ \\
\hline $\mathbf{+ 2}$ & 25 & 12 & 100 & $750-1000$ \\
\hline
\end{tabular}

2.2.2 Effect of Extraction Temperature on Composition Yield of Mucilage

This was determined by percent yield of ash, proteins and viscosity. Viscosity was determined by hydrating MVM ( $1 \%$ $\mathrm{g} / \mathrm{mL}$ ) and equilibrate at $25^{\circ} \mathrm{C}$ before determining viscosity by Brookfield RVT Viscosimeter at $1.5 \mathrm{rpm}$ using spindle No.2. Ash content was determined by UK Essays, (2015) method using $3.0 \mathrm{~g}$ of unpurified mucilage powder $<105$ microns. Protein content was determine by Gebresamuel and Tsige, (2012) method.

\subsection{Physical Properties of Mucilage}

\subsubsection{Micrometric Properties of Mucilage}

Mucilage powder was grounded and fractionated into the size range of 149-250, 105-149 and 74- $105 \mu \mathrm{m} .10 \mathrm{~g}$ from each fraction was transferred into tarred $50 \mathrm{~mL}$ graduated cylinder and tapped at a height of $5 \mathrm{~cm}$ from the bench once and till equilibrium (constant volume). Bulk density $\left(D_{b}\right)$ and tapped density $\left(D_{t}\right)$ was calculated as mass of powder/tap volume, based on one and equilibrium tapings respectively. Hausners index $\left(\mathrm{Dt} / \mathrm{D}_{\mathrm{b}}\right)$ and Compressibility index $\left(1-\mathrm{D}_{\mathrm{b}} /\right.$ $\mathrm{D}_{\mathrm{t})} \times 100$ was then calculated (USP, 2012).

\subsubsection{Solubility Index}

The solubility index was determined by dispersing $0.1 \mathrm{~g}(<74 \mu \mathrm{m}) \mathrm{MVM}$ in $50 \mathrm{~mL}$ distilled water and incubated at temperatures 25,50 and $75{ }^{\circ} \mathrm{C}$ for 30 minutes. It was then centrifuged at $800 \mathrm{rpm}$ for 15 mins and supernatant was dried at $125^{\circ} \mathrm{C}$ until constant weight. Solubility was calculated by the following equation (Sciarini, Maldanado, Ribotta, Perez, $\&$ Leon, 2009).

$$
\text { Solub ility }=(\text { weight } \quad \text { of dried sup erna } \tan t / \text { sample weight }) X 100 \%
$$




\subsubsection{Water Holding Capacity}

This was determined by suspending $1 \mathrm{~g}$ of MVM in $50 \mathrm{~mL}$ distilled water, mixed and centrifuged at $3000 \mathrm{~g}$ for $10 \mathrm{~min}$. The supernatant decanted and water holding capacity was expressed as grams of water absorbed per $100 \mathrm{~g}$ of mucilage (Adebowale, Adeyemi, \& Oshodi, 2005).

\subsubsection{Moisture Sorption}

$1 \mathrm{~g}$ of MVM was placed in Pyrex desiccators containing distilled water. Weight gained after 5 days as percentage of initial weight was used to express moisture Sorption (Medina, Brito-De, Torrestiana, \& Katthain, 2000).

\subsubsection{Swelling Capacity}

$1 \mathrm{~g}$ of MVM was transferred into $25 \mathrm{~mL}$ graduated cylinder and its tap volume determined. It was then disperse in 50 $\mathrm{mL}$ distilled water and kept standing for $24 \mathrm{hrs}$. Volume of hydrated mucilage was noted. Swelling capacity was calculated as the ratio of the hydrated volume to tap volume of dry mucilage (Satheesh, Gayathri, Pradeep, \& Saravanan, (2012).

\subsubsection{Extractive Value}

$1 \mathrm{~g}$ of MVM was grounded with chloroform - water mixture to form a dispersion which was incubated for 24 hrs with regular shaking. It was then centrifuge at $500 \mathrm{rpm}$ for 5 mins. Extractive value determined by the amount of dissolved solid in the supernatant dispersion (UK Essays, 2015).

\subsubsection{Conductivity and $\mathrm{pH}$}

MVM was homogenised in $100 \mathrm{~mL}$ distilled water to get concentration in the range of 0.02 to $1 \% \mathrm{~g} / \mathrm{mL}$ and centrifuged for 5 mins at $500 \mathrm{rpm}$. Conductivity and $\mathrm{pH}$ of supernatant dispersion was then determined by conductometer and $\mathrm{pH}$ meter, respectively.

\subsection{Chemical Characterisation of Mucilage}

\subsubsection{Elemental Composition}

$\mathrm{X}$-ray Fluorescence (XRF) was used to identify and quantify different elements present in M. verticillata mucilage.

\subsubsection{Functional Group Characterization}

Functional groups was determined by Fourier transform infrared (FTIR) spectroscopy. $100 \mathrm{mg}$ of the dried MVM was mixed with $\mathrm{KBr}$ and compressed into discs by applying a pressure of 5 tons in a hydraulic press. The pellet was placed in the light path and infrared spectra recorded between 4000 and $500 \mathrm{~cm}^{-1}$ (Verma, Bansal, Kumar, Malviya, Sharma, \& Kumar, 2014).

\section{Results and Discussions}

\subsection{Optimization of Extraction Methods}

Optimization of extraction condition for aqueous extraction of $M$. verticilata mucilage was studied by varying temperature, time, particle size and amount of solvent. Yield was express as gram of dry MVM per gram of air dry roots bark $(\% \mathrm{~g} / \mathrm{g})$. Mucilage extracted from $M$. verticillata root bark was brown off, amorphous and sticky when moist. Figure 1 below shows the solid mass of MVM during its isolation with ethanol.

Effect of increasing extraction condition (temperature, time and amount of solvent per gram of powder) on yield of mucilage are as displayed in Figure 2. There was statistically significant correlation $(r>1, \mathrm{P}<0.01)$ between temperature and yield of mucilage. This indicates that heat is required during mucilage extraction to reduce viscosity and enhance its release. The insignificant effect $(\mathrm{p}=0.634)$ of temperatures above $50^{\circ} \mathrm{C}$, suggest that there is an optimum amount of heat required to break mucilage cells so as to drive out mucilage.

Release of mucilage was observed to be time dependant (Figure 2) as solvent had to accumulate enough thermal energy so as to penetrate mucilaginous cell, enhance dissolution and transfer of mucilage out of the cell. However, the insignificant effect of time after $3 \mathrm{hrs}$ could be related to degradation of mucilage cell. Decrease in mucilage yield at prolonged extraction time may be due to presence insoluble components which retard solubility of the mucilage (Sepulveda, Saenz, Aliaga, \& Aceituno, 2007).

Result showed a linear correlation $(r=0.353, p=0.033)$ between yield of mucilage and amount of solvent added. This was due to an increase in concentration gradient which enhanced mucilage extraction. High absorption capacity and viscosity of the marc at low ratio tend to trap non polar impurities retarding mucilage solubility and its yield (Najmuldeen, Hariitaraan, Ghasak, \& Zulkafli, 2017). The insignificant effect $(\mathrm{p}=0.284)$ at high ratio was due to saturation of mucilage cell which hindered mass transfer. 
Figure 2 illustrates that yield of mucilage increase with increase in extraction condition (process parameters). There was no significant difference $\left(\mathbf{t}_{8}=1.130, \boldsymbol{p}>\mathbf{0 . 0 5}\right)$ on obtained yield when time and temperature were increased at constant amount of solvent. Positive value of $t$ suggests that increase in both conditions resulted in high yield. Increase in time and volume of solvent at constant temperature resulted in insignificant difference $\left(\mathbf{t}_{8}=-0.341, \boldsymbol{p}>\mathbf{0 . 0 5}\right)$ on yield. Negative value of $t$ suggests that one of the extraction condition contributed strongly to yield more than the other variable. Extraction model, therefore was proposed as shown by the following formula.

$$
Y=8.35+4.39 X_{3}+2.66 X_{2}+1.29 X_{3} \quad \mathrm{R}^{2}=88.2 \% . \quad \text { Equation } 1
$$

Where $\mathrm{X}_{1}$ is time of extraction, $\mathrm{X}_{2}$ is temperature, $\mathrm{X}_{3}$ is solvent volume and $\mathrm{Y}$ is yield of mucilage. High coefficient of time (4.39) indicates that it has more influence on yield than other extraction variables (temperature and volume of solvent).

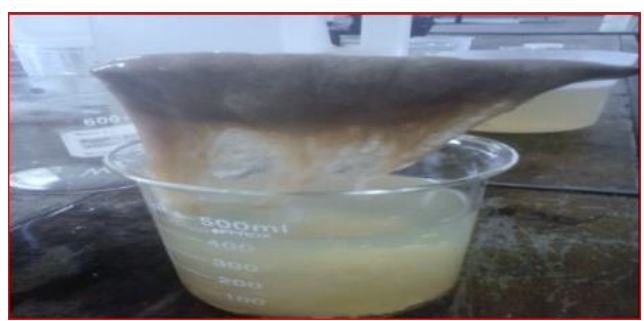

Figure 1. M. verticillata mucilage

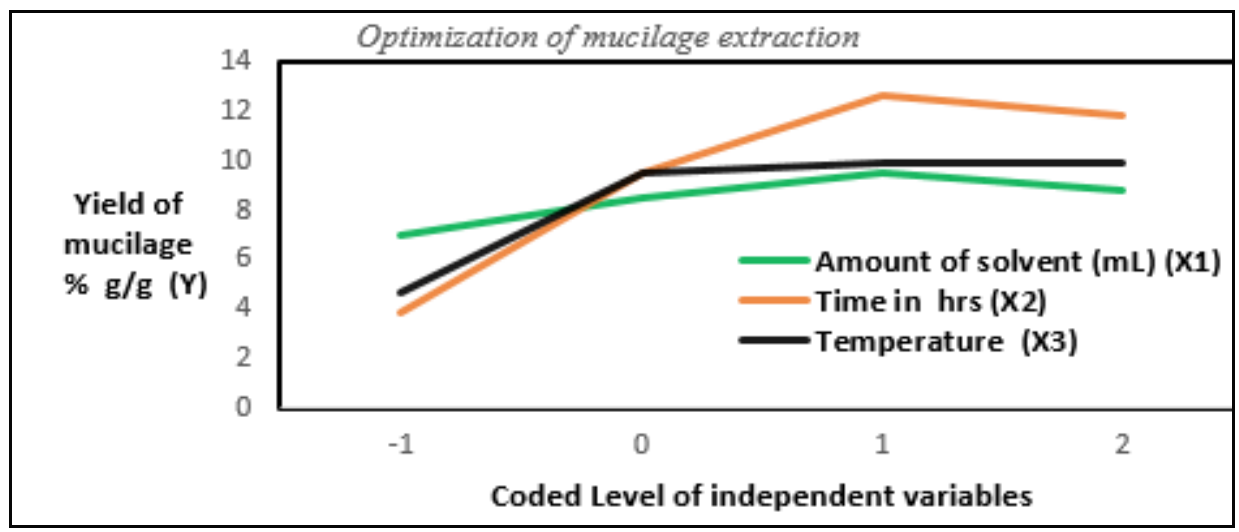

Figure 2. Plots of yield of MVM as a function of Temperature, Time and Amount of solvent used

Figure 3 below shows the effect of particle size on mucilage yield. Result shows that yield obtained from particles < $250 \mu \mathrm{m}$ and $>750 \mu \mathrm{m}$ were low and insignificant $(\mathrm{p}=0.054)$. Lowest yield obtained from particles $>750 \mu \mathrm{m}$ was due to closed mucilage cell which retarded penetration and consequent release of mucilage. While development of impervious film and high viscosity of the marc contributed to low yield as was observed in small Particles less than $250 \mu \mathrm{m}$. Factors like open mucilage cell, even distribution of solvent, efficient mixing, decrease in viscosity of the marc and easy separation of extracted mucilage contributed to the increase in the yield as was observed in the particle of size range of 250-500 $\mu \mathrm{m}$.

Regression analysis of result in Figure 3 prove that there was no correlation $\left.(r=-0.224, p=0.492) R^{2}=70 \%\right)$ between yield and particle size. This indicates that yield does not depend on particle size. Negative correlation and coefficient implies that yield increases with decrease in particle size.

It was observed that yield obtain from sample A was higher than the one obtained from sample B as shown in Figure 3 . The variation was significant $(\mathrm{p}<0.05)$ and therefore it was considered has a hint of components present (Woolfe, Martin, Chaplid, \& Otchere, 1977). High stress due to dry condition, make M. verticillata to synthesis and store more mucilage than in fertile soil, where it store less amount of mucilage. 


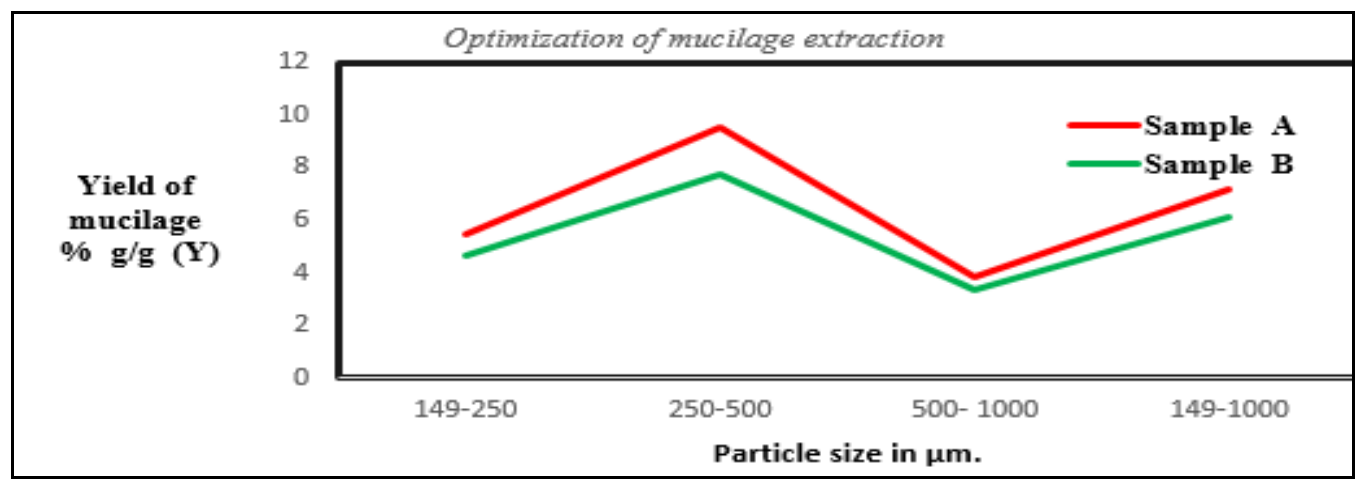

Figure 3. Plots of yield of MVM as a function of Particle size and Sampling sites

Here $[\mathrm{A}]$ and $[\mathrm{B}]$ denote samples collected from Nairobi and Kericho region respectively.

\subsection{Effect of Extraction Temperature on Composition Yield of Mucilage}

Effect of temperature on viscosity, percent yield of ash and proteins are given in Table 2. Increase in temperature had no significant effect $(\mathrm{P}=0.142)$ on yield of ash with the positive correlation $(\mathrm{r}>1)$ being associated with the increase in solubility of inorganic components in the plant material. Amount of water soluble ash were significant as compared to acid insoluble ash. This indicates that most of the salts present in MVM are soluble in water and that there was low contamination by siliceous materials.

The significant $(\mathrm{P}<0.01)$ increase in proteins with temperature was due to the use of excess solvent at high temperature, co-precipitation by ethanol and presence of fat which create lipophilic environment. Despite purification, high percentage of proteins was retained by mucilage (Table 2). This may infer existence of a strong interaction between protein and components of mucilage. The negative correlation $(\mathrm{r}<1, \mathrm{p}=0.015)$ between viscosity and temperature indicates that high extraction temperature yield mucilages which are of low viscosity. This observation can be associated with irreversible weakening of intermolecular forces and denaturing of proteins (Gebresamuel and Tsige, 2012).

Table 2. Effect of extraction temperature on composition of M. verticillata mucilage

\begin{tabular}{|llllllll|}
\hline & \multicolumn{2}{c}{ Ash in \% g/g } & & \multicolumn{2}{c}{$\begin{array}{l}\text { Total Proteins } \\
\text { in \% g/g }\end{array}$} & \multicolumn{2}{c|}{ Viscosity in cps } \\
\hline $\begin{array}{l}\text { Temperature } \\
\text { in }{ }^{\circ} \mathrm{C}\end{array}$ & $\begin{array}{l}\text { Total } \\
\text { Ash }\end{array}$ & $\begin{array}{l}\text { Insoluble } \\
\text { Ash }\end{array}$ & $\begin{array}{l}\text { Water } \\
\text { soluble Ash }\end{array}$ & $\begin{array}{l}\text { Crude } \\
\text { MVM }\end{array}$ & $\begin{array}{l}\text { Purified } \\
\text { MVM }\end{array}$ & $\begin{array}{l}\text { Crude } \\
\text { MVM }\end{array}$ & $\begin{array}{l}\text { Purified } \\
\text { MVM }\end{array}$ \\
\hline 25 & $14.41 \pm 0.49$ & $1.04 \pm 0.05$ & $9.03 \pm 0.19$ & $4.12 \pm 0.22$ & $2.12 \pm 0.37$ & $2.47 \pm 0.16$ & $2.17 \pm 0.42$ \\
\hline 50 & $14.63 \pm 0.37$ & $0.93 \pm 0.04$ & $12.27 \pm 0.05$ & $5.66 \pm 0.45$ & $3.25 \pm 0.41$ & $2.48 \pm 0.19$ & $2.15 \pm 0.32$ \\
\hline 75 & $15.09 \pm 0.08$ & $0.88 \pm 0.07$ & $12.78 \pm 0.06$ & $6.43 \pm 0.09$ & $2.03 \pm 0.35$ & $1.81 \pm 0.25$ & $1.08 \pm 0.43$ \\
\hline
\end{tabular}

Therefore, the optimum condition for extraction of mucilage from M.verticillata root bark were powder to volume ratio of 1:20 for $3 \mathrm{hrs}$ at $50^{\circ} \mathrm{C}$ using particle size in the range of $250-500 \mu \mathrm{m}$. This condition resulted in high yield, pervious mucilage, and of high viscosity with low protein content. High temperature yielded mucilage which was of low viscosity, poor solubility and high percentage of proteins. Longer time of extraction compromises microbial contamination while use of excess solvent results in high yield of mucilage due to occlusion of impurities and consumes a lot of dissolvating solvent.

\subsection{Micrometric Properties of Mucilage}

Micrometric properties of MVM as a function of particle size are as shown in Table 3. Difference in tapped and bulk density depicts mucilage particles to be surface active with better packing rearrangement. tapped density was higher than bulk density to suggests that tapping causes interparticle attraction and interlocking. Obtained values of $\mathrm{CI}<30>11$ and $\mathrm{HI}<1.45>\mathrm{I} .12$ shows that MVM exhibits mixed cohesiveness and free-flowing behaviour. These properties are influenced by processes such as grounding which increases surface area, moisture content which bridge by capillary force and amorphous nature of particles which contribute to interlocking (Fitzpatrick and Ahrne, 2005). 
Table 3. Effect of particle size on Micrometric properties of MVM

\begin{tabular}{|lllll|}
\hline $\begin{array}{l}\text { Pertical } \\
\text { size in } \mu \mathrm{m}\end{array}$ & $\begin{array}{l}\text { Bulk density } \\
\mathrm{g} / \mathrm{ml}\end{array}$ & $\begin{array}{l}\text { Tap density } \\
\mathrm{g} / \mathrm{ml}\end{array}$ & $\begin{array}{l}\text { Hausner's } \\
\text { index HI }\end{array}$ & $\begin{array}{l}\text { Compressibility } \\
\text { index CI in \% }\end{array}$ \\
\hline $74-105$ & $0.822 \pm 0.010$ & $1.146 \pm 0.08$ & $1.39 \pm 0.009$ & $28.22 \pm 0.44$ \\
\hline $105-149$ & $0.726 \pm 0.005$ & $0.923 \pm 0.06$ & $1.27 \pm 0.001$ & $21.17 \pm 0.32$ \\
\hline $149-250$ & $0.723 \pm 0.004$ & $0.818 \pm 0.006$ & $1.13 \pm 0.01$ & $11.66 \pm 0.714$ \\
\hline
\end{tabular}

\subsection{Physical Properties of Mucilage}

Results displayed in Table 4 shows that temperature does not influence solubility of MVM in water. The insignificant correlation $(r>1, p=0.067)$ between solubility and temperature suggests that the intermolecular interaction become weak as temperature increases (Doublier and Cuvelier, 2006). Low solubility of MVM in water was due to presence of proteins, fats and formation of mucilaginous and hydrated magnesium film. Ability of mucilage to form dispersion was found to decreases with increase in concentration, temperature and force of centrifugation. Solubity of MVM was observed to be independent of sampling areas.

Table 4. Effect of Temperature on Solubility of M. Verticillata mucilage in water

\begin{tabular}{|ccccc|}
\hline Temperature in ${ }^{\circ} \mathrm{C}$ & & 25 & 50 & 75 \\
\hline $\begin{array}{c}\text { Solubility } \\
\text { in } \%\end{array}$ g/g & Sample A & $44.22 \pm 1.09$ & $50.39 \pm 0.83$ & $48.36 \pm 0.76$ \\
\cline { 2 - 5 } & Sample B & $45.59 \pm 1.91$ & $49.48 \pm 1.13$ & $49.77 \pm 1.66$ \\
\hline
\end{tabular}

M.verticillata mucilage had ability to absorb and retain water when subjected to centrifugation stress and humid environment. This was shown by water holding, moisture sorption and swelling capacity (Table 5). The difference in swelling and water holding capacity explains the effect of centrifugation force on capability of mucilage to bind water. Absorption of water by mucilage resulted in swelling, conformational changes and interactions between permeating water and polar groups of mucilage (Diab, Biliaderis, Gerasopoulos, \& Sfakiotakis, 2001). Hydroxyl groups enable mucilage to absorb, retain and interact with water, while presence of calcium and proteins block water binding sites by forming insoluble complexes (Fedeniuk and Biliaderis, 1994).

High extractive value of $>80 \%$ and moisture content of $>13 \%$ (Table 5) indicates that most of mucilage constituents are water extractable and residual water exist in hydrated form, in bondage with glycoside. This characteristic implies that MVM has high tendency to microbial attack (Dafam, Abu-Bakr, Nuhu, Ajima, \& Okwori, 2013).

Table 5. Hydration properties of M. verticillata mucilage

\begin{tabular}{|llllll|}
\hline & Swelling Capacity v/v & Water Holding $\% g / g$ & Moisture Sorption $\% g / g$ & Extractive $\% g / g$ & Moisture content $\% g / g$ \\
\hline Sample A & $1.45 \pm 0.07$ & $17.2 \pm 1.26$ & $34.53 \pm 3.05$ & $80.15 \pm 3.64$ & $13.21 \pm 1.12$ \\
\hline Sample B & $1.39 \pm 0.11$ & $14.12 \pm 1.76$ & $28.51 \pm 2.3$ & $79.25 \pm 2.48$ & $14.17 \pm 1.15$ \\
\hline
\end{tabular}

Result in Table 6 shows that $\mathrm{pH}$ of MVM increases significantly $(\mathrm{p}<0.01)$ with increase in concentration. MVM was found to be alkaline with the conductivity increasing significantly $(\mathrm{p}<0.01)$ with increase in mucilage concentration. This indicates that mucilage dissociates in water to yield mobile ions that can generate electrical stress. Insignificant increase in conductivity ( $\mathrm{p}>0.05$ ) at higher concentration and small deviation in $\mathrm{pH} \pm 0.3$ indicates that the mucilage is fairly stable in aqueous environment.

Table 6. $\mathrm{pH}$ and Conductivity of $M$. verticillata mucilage

\begin{tabular}{|cccccc|}
\hline $\begin{array}{c}\text { Concentration } \\
\mathrm{g} / 100 \mathrm{~mL}\end{array}$ & 0.1 & 0.25 & 0.5 & 0.75 & 1 \\
\hline $\mathrm{pH}$ & $7.55 \pm 0.04$ & $7.63 \pm 0.03$ & $7.71 \pm 0.01$ & $7.82 \pm 0.04$ & $7.91 \pm 0.05$ \\
\hline $\begin{array}{c}\text { Conductivity } \\
\mu \mathrm{S} / \mathrm{cm}\end{array}$ & $352 \pm 10.45$ & $596 \pm 10.03$ & $860 \pm 8.53$ & $1140 \pm 12.05$ & $1151 \pm 9.61$ \\
\hline
\end{tabular}

\subsection{Chemical Properties of Mucilage}

Composition and proportion of mineral present was found to be constant and independent of sampling areas as shown in Table 7. Presence of calcium and sulphur makes $M$. verticillata mucilage exist of complex compound entities (Nuhu and Abdullahi, 2009; Senthil et al., 2010). The hard compact mass of the mucilage formed on drying may be attributed to presence of magnesium which interact with water and atmospheric oxygen leading to formation of knit-webbed 
mucilage structure. Loss on ignition (LOI) indicates that MVM contain high proportion of carbon and bound water. Presence of Aluminium, chloride and sulphate may limit the mucilage application as pharmaceutical adjuvant (USP, 2012).

Table 7. Elemental composition of M.verticillata mucilage in \%

\begin{tabular}{|c|c|c|c|c|c|c|c|c|c|c|}
\hline \multirow{2}{*}{$\begin{array}{l}\text { Sampling } \\
\text { Region }\end{array}$} & \multicolumn{10}{|c|}{ Elemental composition } \\
\hline & $\mathrm{K}$ & $\mathrm{Na}$ & $\mathrm{Ca}$ & $\mathrm{Mg}$ & Al & $\mathrm{P}$ & $\mathrm{Si}$ & s & $\mathrm{Cl}$ & LOI \\
\hline Sample A & $15.07 \pm 1.99$ & $6.17 \pm 1.14$ & $22.08 \pm 1.38$ & $4.34 \pm 0.5$ & $3.69 \pm 0.31$ & $7.34 \pm 0.51$ & $5.72 \pm 0.43$ & 2.19 & 0.57 & 85.65 \\
\hline Sample B & $6.56 \pm 1.55$ & $1.86 \pm 0.66$ & $29.91 \pm 1.05$ & $0.96 \pm 0.13$ & $1.82 \pm 0.66$ & $2.58 \pm 0.42$ & $4.54 \pm 0.38$ & 0.86 & 0.36 & 79.41 \\
\hline
\end{tabular}

Figure 4 shows FTIR spectra bands of $M$. verticillata mucilage. The picks at 798.8 and $1148.2 \mathrm{~cm}^{-1}$ represent C-O and $\mathrm{C}-\mathrm{O}-\mathrm{C}$ finger print region for carbohydrates. The presence of $\mathrm{C}-\mathrm{O}$ and $\mathrm{O}-\mathrm{H}$ entities in the carbohydrate unit is further corroborated with the absorption bands appearing at $1002.4 \mathrm{~cm}^{-1}$ and $3471.22 \mathrm{~cm}^{-1}$ (broad), respectively (Kemp, 1991). The weak signals at $3025 \mathrm{~cm}^{-1}$ and $2907.6 \mathrm{~cm}^{-1}$ represent stretching of $\mathrm{N}-\mathrm{H}$ in proteins and $\mathrm{C}-\mathrm{H}$ in the pyranose group, respectively (Han, Gao, Yin, .Jin, \& Chen, 2016). The absence of one of absorption bands associated with carboxylic group $\left(1680 \mathrm{~cm}^{-1}, \mathrm{~s}\right)$ indicates the absence of uronic acid which is usually present in a number of plant mucilages (Monrroy et al., 2017).

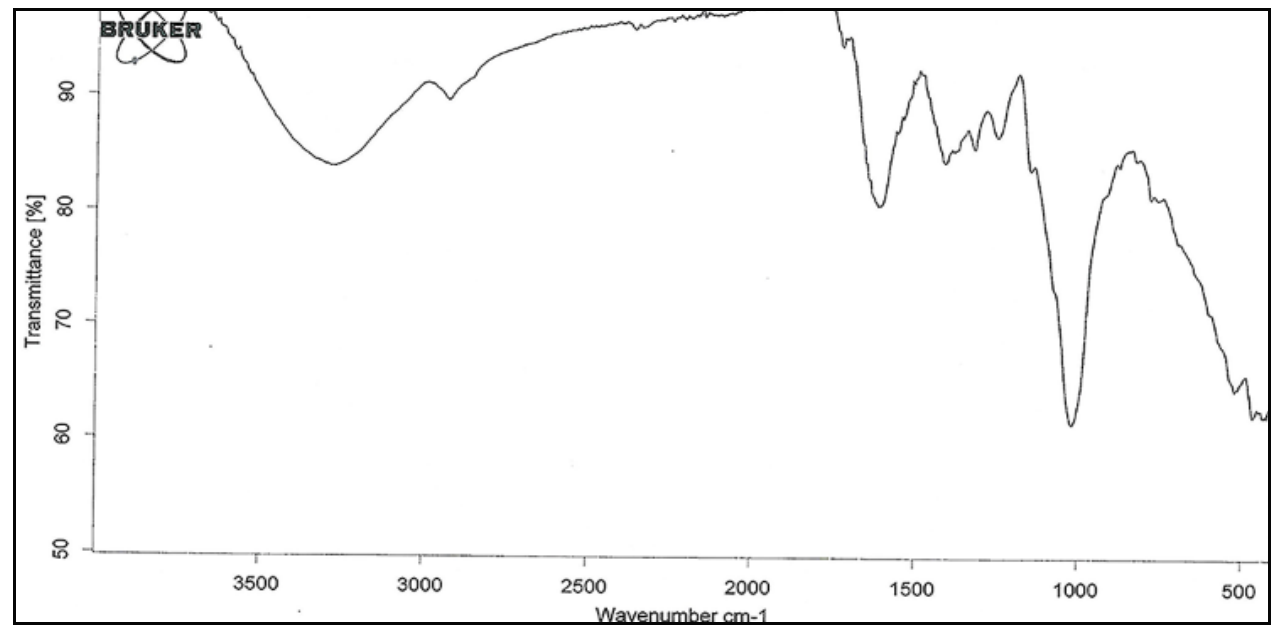

Figure 4. FTIR Spectrum of M. verticillata mucilage

\section{Conclusion}

Malva verticillata mucilage is amorphous, cohesive and sticky when moist. Its solubility in water depends on the process of grounding and not temperature. Low temperature and short duration results in more dispersible mucilage with high viscosity. Yield and composition of mucilage depends on extraction conditions and not particle size. $M$. verticillata mucilage have ability to hold water, high tendency to microbial attack and exist as a polysaccharides complex of calcium. Absence of tannins and constant composition independent of sampling areas suggests the high potential of the mucilage as pharmaceutical adjuvant subject to biocompatibility evaluation.

\section{Acknowledgements}

The authors would like to acknowledge the financial support for the research work from the National Council for Science, Technology and Innovation (NACOSTI-Kenya) through PC Korir. We thank Mr P. Mutiso of University of Nairobi Herbarium for verification and identification of plant samples.

\section{Conflicts of Interest}

The authors declare no conflict of interest.

\section{References}

Adebowale, Y. A., Adeyemi, I. A., \& Oshodi, A. A. (2005). Functional and physicochemical properties of flours of six Mucuna species. African Journal of Biotechnology, 4(12), 1461-1468.

Alalor, C. A., Avbunudiogba, J. A., \& Augustine, K. (2014). Isolation and characterization of mucilage obtained from Colocasia esculenta. International Journal of Pharmacy and Biological Sciences, (1), 25-29. 
Amin, M. A., Shamsuddin, A. A., Yinyin, Y., Yahya, N., \& Ibrahim, N. (2007). Extraction, purification and characterization of durian (Durio zibethinus) seed gum. Food Hydrocolloids, 21, 273-279.

Bruneton, J. (1999), Photochemistry of Medicinal Plants, Lavoisier Publishing, New York, $2^{\text {nd }}$ Edition, 90-91.

Chaudhary, A., Kulkarni, G. T., Rajendra, A., \& Kumar, P. (2016). Investigation on binding properties of Grewi asiatica mucilage in tablet formulations. Mar. Pharm. J., 20(3), 353-367. https://doi.org/10.12991/mpj.201620325882588

Dafam, D. G., Abu-Bakr, M. S., Nuhu, H., Ajima, U., \& Okwori, V. (2013). Quantitative Evaluation of Some Physical and Chemical Properties of the Gum-Mucilage of Anacardium Occidentale L (Anacardiaceae). International Journal of Pharmaceutical Science Invention, 2(9), 46-48.

Diab, T., Biliaderis, C., Gerasopoulos D., \& Sfakiotakis, E. (2001). Physicochemical properties and application of pullulan edible films and coatings in fruit preservation. Journal of the Science of Food and Agriculture, 81, 988-1000. carried out at greater than $900^{\circ} \mathrm{C}$, preferably at $1000^{\circ} \mathrm{C}$, and that, in practice, $1 \mathrm{hr}$. https://doi.org/10.1002/jsfa.883

Doublier, J. L., \& Cuvelier, G. (2006). Gums and Hydrocolloids: Functional Aspects. In: A.C. Eliasson (Editeur). Carbohydrates in foods, 232-272. https://doi.org/10.1201/9781420015058.ch7

Fedeniuk, R. W., \& Biliaderis, C. G. (1994), Composition and physicochemical Properties of linseed (Linum usitatissimum L.) mucilage. Journal of Agricultural and Food Chemistry, 42, 240-247. https://doi.org/10.1021/jf00038a003

Fitzpatrick, J. J., \& Ahrne, L. (2005). Food powder handling and processing: Industry problems, knowledge barriers and research opportunities. Chem. Eng. Proc., 44, 209-214. https://doi.org/10.1016/j.cep.2004.03.014

Gebresamuel, N., \& Tsige, G. M. (2012). Comparative Physico-Chemical Characterization of the Mucilages of Two Cactus Pears (Opuntia spp.) Obtained from Mekelle, Northern Ethiopia. Journal of Biomaterials and Nanobiotechnology, 3, 79-86. https://doi.org/10.4236/jbnb.2012.31010

Goycoolea, F. M., \& Cárdenas, A. (2003). Pectin's from Opuntia spp; A Short Review. Journal of the Professional Association for Cactus Development, 5, 17-29.

Han, Y. L., Gao, Y. Y., Yin, Z. Y., Jin, X., Xu, M., \& Chen, H. Q. (2016). Extraction optimization by response surface methodology of mucilage polysaccharide from the peel of Opuntia dillenii haw. Fruits and their physicochemical properties. Carbohydrate Polymers, 151, 381-391. https://doi.org/10.1016/j.carbpol.2016.05.085

Kemp, W. (1991). Organic Spectroscopy, $3^{\text {rd }}$ ed. Macmillan, Hong Kong, 59-83, 122-127. https://doi.org/10.1007/978-1-349-15203-2

Laurence, J. D. (2007-2010). Malva verticillata L, the Integrated Taxonomic Information System, ITIS, 21841 Taxonomic Serial No. 21841.

Medina, L. T., Brito-De, L. F. E., Torrestiana, S., \& Katthain, R. (2000). Rheological properties of the mucilage gum (Opuntia ficus indica). Food Hydrocolloids, 14, 417-424. https://doi.org/10.1016/S0268-005X(00)00015-1

Monrroy, M., García, E., Ríos, K., \& Renán, J. (2017). Extraction and Physicochemical Characterization of Mucilage from Opuntia cochenillifera (L.). Journal of Chemistry, 2017, Article ID 4301901. https://doi.org/10.1155/2017/4301901

Najmuldeen, G. F., Hariitaraan, F., Ghasak, G. F., \& Zulkafli, H. (2017). Characterization of Eurycoma longifolia (Tongkat Ali) Essential Oils Extracted by Microwave Assisted Extraction. Journal of Applied Pharmaceutical Science, (6), 62-68. https://doi.org/10.7324/JAPS.2017.70609

Nuhu, A., \& Abdullahi, A. T. (2009). Determination of the Physio-Chemical Properties of Nigerian Acacia Species for Foundry Sand Binding Applications. Research Journal of Applied Sciences, Engineering and Technology, 1(3), 107-111.

Patel, N. C., Shah, N. S., Mahajan, A. N., \& Dushyant, A. S. (2011). Isolation of Mucilage from Cydonia vulgaris Pers. Seeds and its Evaluation as Superdisintegrant. Journal of Applied Pharmaceutical Science, 1(04), 110-114.

Satheesh, B. N., Gayathri, R., Pradeep, R., \& Saravanan, T. L. (2012). Isolation and characterization of Araucaria heterophylla mucilage. International Journal of Phytopharmacy Research., 3(1), 6-8.

Sciarini, L. S., Maldanado, F., Ribotta, P., Perez, G. T., \& Leon, A. E. (2009). Chemical composition and functional properties of Gleditsia triacanthos gum. Food Hydrocolloids, 23(2),

306-313. https://doi.org/10.1016/j.foodhyd.2008.02.011 
Senthil, S. R., Gopalkrishnan, S., Ramajayam, M., \& Rahul, S. (2010). Evaluation of mucilage of Caesalpinia pulcherrima as Binder for Tablets. International Journal of Chem Tech Research, 2(1), 436-442.

Sepulveda, E., Saenz, C., Aliaga, E., \& Aceituno, C. (2007). Extraction and characterization of mucilage in Opuntia spp. Journal of Arid Environments, 68(4), 534-545. https://doi.org/10.4236/jbnb.2012.31010

Singthong, J., Ningsanond, S., \& Cui, S. W. (2009). Extraction and physicochemical characterisation of polysaccharide gum from Yanang (Tiliacora triandra) leaves. Food Chem., 114, 1301-1307.

Thanatcha, R., \& Pranee, A. (2011). Extraction and characterization of mucilage in Ziziphus mauritiana Lam. International Food Research Journal, 18, 201-212.

UK Essays. (2015). Pharmacognostic Investigation and Quality Control of Crude Drugs Biology Essay.

United States Pharmacopeia Convention, 2012, XXV -616.

Verma, S., Bansal, J., Kumar, N., Malviya, R., Sharma, P., \& Kumar, S. (2014). Isolation and characterization studies of mucilage obtained from trigonella foenum greacum L. seed and tamarindus indica polysaccharide as a pharmaceutical excipient. Journal of Drug Delivery \& Therapeutics, 4(3), 106-109.

Woolfe, M. L., Martin, F., Chaplid, \& Gifty, O. (1977). Studies on the Mucilages Extracted from Okra Fruits (Hibiscus esculentus L.) and Baobab Leaves (Adansonia digitata L.). J. Sci. Fd. Agric., 28, 519-529.

https://doi.org/10.1002/jsfa.2740280609

\section{Copyrights}

Copyright for this article is retained by the author(s), with first publication rights granted to the journal.

This is an open-access article distributed under the terms and conditions of the Creative Commons Attribution license (http://creativecommons.org/licenses/by/4.0/). 